\title{
The Impacts of Private Banks on Economic Growth in Ethiopia
}

\author{
Yonas Yohannes Tamrat Guja Asale \\ College of Business and Economics, Wolaita Sodo University, Ethiopia
}

\begin{abstract}
An improvement in nation's economic growth is contributed by major functions of private Banks such as deposit mobilization, giving credit to entrepreneurs, financing investment and foreign currency purchase and remittances. However, it is adversely affected due to an increasing amount of Banks non-performing loans in the long run. The studies that had been conducted on the banking sector focused on the general policy, capacity, the Bank performance and quality of service on customer satisfaction. Hence the objectives the study was to examined the short and long run impact of private Banks on economic growth in Ethiopia. The time series data which covering 1994/95 to 2015/16 from National Bank of Ethiopia was analyzed by employing VECM by using e-views software. The result indicates that deposit mobilization, investment, foreign remittance and purchase have positive and significant relationship with GDP with the coefficients of $0.8096,0.1052$ and 0.0297 respectively. The coefficients imply that for one unit rise in deposit mobilization of private Banks causes an increase of GDP by 0.8096 units, for one unit rise in investment of private Banks cause an increase in GDP by 0.1052 units and for one unit rise in foreign remittance and purchase of private Banks cause an increase in GDP by 0.0297 units respectively. Therefore, private Banks are playing indispensable role on the economic growth in Ethiopia by performing their primary functions in the economic activities. Hence, to accelerate economic growth, Banks should collect deposit from every corner of the country so as to finance larger investment projects.
\end{abstract}

Keywords: economic growth, private Banks, deposit, investment, VECM

DOI: $10.7176 / \mathrm{JESD} / 10-11-06$

Publication date:June $30^{\text {th }} 2019$

\section{Introduction}

Banks have been perceived as engine of economic growth because they perform resource allocation function, by mobilizing and channeling resources from surplus economic units to deficit units. The financial systems have long history and paramount contribution to economic betterment and social wellbeing in Ethiopia starting from traditional systems like Ekub and Idir to the Bank of Ethiopia which was the first indigenous Bank in Africa and established by an official decree in 1931 (Gebeyehu, 2008). The government of Ethiopia has declared a liberal economic system with Monetary and banking proclamation of 1994 established the national Bank of Ethiopia as a judicial entity and outlined its main functions. This is considered as turning point in the history of banking business where local private Banks are allowed to operate in the country. Growing economy in Ethiopia is sparking more investment in the banking business, expanding the industry in which more and more private Banks are emerging. Given the good performance of the economy and attractive profits declared by private Banks from year to year, investors are attracted to invest in this sector with the hope that the future value of their shares will be high (Befikadu, 2015).

Expanding the number of Banks as well as branches of existing Banks will create the greater saving opportunity which will in turn boost economic growth of the country (Nigussie, 2012). Private Banks in Ethiopia play a significant role in economic growth of the country by supporting the investment opportunities. It is accepted without deny that public sector Banks lead investment in key developmental projects which involves infrastructure and requires huge amounts of capital. But to bring a broad based and sustainable development in the country, the investment fund typically comes from private Banks as their deposit base grows. Through their financial intermediary services, Banks mobilize funds within and outside the country and channels such funds to various productive sectors of the economy (Gebeyehu, 2008). Banks as financial intermediary institutions provides a venue for people to save incomes not spent on consumption. It is from the savings they accumulate that they are expected to extend credit facilities to entrepreneurs and other industrialists (Keating, 2014). By doing such kinds of functions private Banks facilitates the economic growth of the country.

The main objective of allowing the private sector to engage in the banking business was to mobilize deposits from every part of the country, providing credit access to investors and dealing with foreign exchanges with the use of its employees. In this regard, this paper would empirically investigate the impact of private Banks on Economic growth in Ethiopia with the use of major functions of private Banks which are performed by its employees.

\subsection{Statement of the problem}

Banks play several vital roles in any economy by ensuring sound financial system and economic stability. Several economic theories and empirical evidences shows that functions of formal financial institutions and economic 
growth have direct relationship both in developed and developing countries. This implies that Banks exist to play a significant role in mobilizing resources particularly domestic saving from the public and allocating them to various investment activities in the form of domestic credits (Gebeyehu, 2008). The development of banking industry in general and development of private Banks in particular needs potential policy actions to fill the gap between primary functions of private Banks and economic growth.

However, Banks' ability to stimulate economic growth and development depends on the health, soundness and stability of the banking system itself (Alex, 2012). The Banking sector in Ethiopia is at its rudimentary and fragile shape, relatively undeveloped and characterized by a large share of state ownership which is closed from foreign competition. The state-owned commercial Banks account for nearly two-thirds of the Banking sector assets (Bezabeh and Desta, 2014). In Ethiopia, among primary functions of the commercial Banks, there is low level of saving to finance increasing customer's demand that in turn results low level of investment.

Their primary functions have an impact on Economic growth in Ethiopia and they are playing decisive role in the Ethiopian economy both in short run and long run. However; at the same time challenges exist in their operations and its primary functions linkage with economic growth on Ethiopian economy is not given due attention. Currently, the financial sector in Ethiopia is composed of the Banking industry, insurance companies, microfinance institutions, saving and credit cooperatives and the informal financial sectors.

Therefore, it is possible to say that private Banks have positive impacts of on Economic growth in Ethiopia through its major functions such as deposits mobilized, credit given to entrepreneurs, investment financed and foreign remittances (Melkamu, 2015). Hence, there will be a higher economic growth in times of higher investment in the country where investment fund is collected by Banks in the form of saving. However, it is adversely affected due to an increasing amount of Banks non-performing loans in the long run. The studies that had been conducted were focused on the general policy, capacity, Bank performance, the quality of service and competition among the of the Bank one and on the other hand the service quality of private Banks and its impact on customer satisfaction. Hence the current study intended to look in depth about the impact of private Banks on Economic growth in Ethiopia by taking its major functions and factors of production.

\subsection{Objectives of the study}

The general objective of the study was to analyze the impact of private Bank on economic growth in Ethiopia. 1.3.1 Specific objectives

1. To describe the contribution of primary functions of private Banks on economic growth

2. To investigate the short and long run impact of private Banks on economic growth

\section{Research Methodology}

\subsection{Sources and methods of Data collection}

Currently, there are eighteen Banks in NBE which comprises seventeen commercial Banks and one development Bank. While Ethiopian development Bank and commercial Bank of Ethiopian are government owned, the remaining sixteen are private owned those were considered in the study. The current study employed time series secondary data which covering 1994/95-2015/16 were collected from National Bank of Ethiopia.

\subsection{Methods of Data Analysis}

Both descriptive and econometric data analysis methods were employed. Regarding to econometrics methods, vector error correction model (VECM) was used by using e-view software to examine the impact of private Banks on Economic growth in Ethiopia both in short run and long. Regarding to the model specification the VECM is adopted to see the long run and short run relationship between independent variables (deposit mobilized investment, transfer and purchase of foreign currency, credit) and dependent variable (GDP). The model was adopted by Orji (2012) and rearranged as:

$\mathrm{GDP}=\mathrm{f}(\mathrm{dm}, \mathrm{di}, \mathrm{cr}, \mathrm{fcy})-------------------------3.1$

$\mathrm{GDP}=\alpha+\beta 0 \mathrm{dm}+\beta 1 \mathrm{in}+\beta 2 \mathrm{cr}+\beta 3 \mathrm{fcy}+\mathrm{e}---------------------3.2$

Whereas GDP, dm, din, cr, fcy and Lf represents gross domestic product, deposit mobilization, investment, credit and foreign remittances and labor force respectively. $\alpha$ Stands for constant and $\beta 0-\beta 3$ are coefficient of the respective variables and e stands for error term. When the equation changed in to the log form on the e-views package it presented as follows;

$\ln G D P t=\alpha+\beta 0 \operatorname{lndm}+\beta 1 \operatorname{lnin}+\beta 2 \operatorname{lncr}+\beta 3 \ln f c y t+\varepsilon t-----------3.3$

\section{Results and Discussion}

\subsection{Descriptive Statistics}

The major functions of private Banks as indicators to know the impact of private Banks on GDP, a measure of economic growth in Ethiopia. 
Table 1 Results of descriptive statistics

\begin{tabular}{lrrrrrr}
\hline Variables & Mean & Median & Std. Dev. & Maximum & Minimum & Probability \\
\hline Log of GDP & 5.435638 & 5.369218 & 0.220667 & 5.839494 & 5.144512 & 0.368726 \\
Log of DEP & 4.722076 & 4.616881 & 0.50609 & 5.641626 & 4.004714 & 0.429916 \\
Log of FCY & 2.182073 & 2.816375 & 1.43621 & 3.601024 & 0 & 0.1954 \\
Log of INVS & 6.205352 & 6.152795 & 0.214232 & 6.653063 & 5.815756 & 0.873498 \\
Log of CR & 3.600912 & 3.955313 & 1.329545 & 4.969331 & 0 & 0.000165 \\
\hline
\end{tabular}

Source: - own computation result data from NBE, 2016

As the results shown in the table1, that GDP has a mean of 54.3 percent with minimum and maximum values are 51.4 and 58.4 percent respectively. With regard to explanatory variables the means of deposit, foreign currency purchase and remittance, domestic investment and credit 47.2, 21.8, 62 and 36 percent respectively. The mean of deposit is found to be 47.2 percent indicating that on average the private commercial Bank has a deposit to GDP ratio of 47.2 percent per annum. Moreover, a deposit which is mobilized by private commercial Bank as measured by the ratio of deposit to GDP found in between 40 percent to 56.4 percent. Similarly, foreign currency purchase and remittance transfer by private commercial Bank as measured by the ratio of foreign currency purchase and remittance to GDP found in between 0 to 36 percent. From these the domestic investment financed by private Banks in Ethiopia is measured by investment to GDP is about 62 percent per year with a minimum and maximum values lies in between 58.1 to 66.51 percent respectively.

\subsection{Results of Vector Error Correction Model (VECM)}

VECM designates both the long run and the short run dynamics relationship. The change in the given variable from its short run effect represents a variation in the short run; the coefficient of the error correction term captures the speed of adjustment towards the long-run relationship of variables.

Table 2 Long run equilibrium VECM Estimate

\begin{tabular}{lcccc}
\hline Variables & Coefficients & standard error & t-statistics & p-values \\
\hline & & & & - \\
Constant & 2.1936 & - & - & - \\
Deposit & 0.8096 & 0.01373 & {$[58.9449]$} & $0.00^{* * *}$ \\
Investment & 0.1052 & 0.01711 & {$[6.14732]$} & $0.00^{* *}$ \\
Credit & -0.3489 & -0.00344 & {$[101.377]$} & 0.985 \\
Foreign currency \&remittance & 0.0297 & 0.00348 & {$[8.55978]$} & $0.021^{* *}$ \\
\hline & & & & 0.090357 \\
\hline R-squared & 0.813518 & Mean dependent VAR & & 0.040558 \\
\hline Adjusted R-squared & 0.786576 & S.D. dependent VAR & & 0.054133 \\
S.E. of regression & 0.032706 & Sum squared residual & & 0.000 \\
Durbin-Watson stat & 1.788944 & Prob(F-statistic) & & \\
\hline
\end{tabular}

Source: - own computation result data from NBE, 2016

As we can see from the table 2, deposit mobilization, domestic investment and foreign currency and remittance are proved to be significant at 1 and 5 percent levels of significance respectively. Therefore, from the above analysis of the betas, it can be inferred that the results of the betas total deposit mobilization contributes a lot to GDP followed by domestic investment and foreign currency remittance and purchase. The numerical value of adjusted R2 is $78 \%$ that indicates that the independent variables are collectively 78 percent related to the dependent variable GDP.

Deposit mobilization has positive relationship with GDP at 1 percent significance. As it can be revealed in the table 2, the coefficient of deposit mobilization is 0.8096 which can be interpreted as for one unit rise deposit mobilization private Banks causes an increase of GDP by 0.8096 units. This implies that an increase in deposit mobilization indicates that the commercial Banks are able to collect deposits from a wider customer base hence increasing the amounts available to commercial Banks for lending. With increased lending levels in the country, more funds are available to be invested in different sectors hence positively impacting on economic growth registered. On the other hand, the degree of monetization in the economy as well as the expansion of payments and saving functions which are performed by commercial Banks in the development process of Ethiopia. This is consistent with the study of Aurangzeb (2012) in the amount of commercial Bank's deposit increases the economic growth which is measured by GDP. Again it is consistent with the directive of national Bank of Ethiopia which states that all private Banks in Ethiopia mobilize their funds from shareholders contribution, their operational profits and from customers' deposit mobilization. This directive instructs that all private Banks should purchase government bonds on $27 \%$ of all loan disbursements (NBE Directive no: MFA/NBEBILLS/001/2011). When the deposit mobilization of private Banks increases, it contributes its share significantly to the country's economic growth. Therefore, private Banks are playing indispensable role in facilitating transactions using their mobilized 
resources in the economic activities.

Investment has positive relationship with GDP at 1 percent significance level. The coefficient of investment shown in the table 4.2 can be interpreted as that a one unit investment increase leads an increase in GDP by 0.1052 units. The result is consistent with the study of Andebet (2016) which states that primary role of commercial Banks is to mobilize deposit and avail such recourse for domestic investment. Financing the investment sector is one of the primary functions of private Banks that positive impact on the Economic growth in Ethiopia.

The foreign currency purchase and remittance transfer has positive and significant relationship with GDP at $5 \%$ significance level. The coefficient of foreign remittance and purchase can be interpreted as that a one unit foreign remittance and purchase increase leads an increase in GDP by 0.0297 units. The numerical value of its coefficient shows that a one unit increment in the foreign remittance and purchase causes the GDP of Ethiopia to increase by 0.0297 units. Therefore, private Banks purchases hard currencies and provides the remittance service from the rest of world. By providing such kind of service they are contributing positively towards the economic growth of Ethiopia.

The short-run dynamic includes simultaneous current effects, short-run adjustment effects to lagged changes to the variable and previous equilibrium errors in the system. Identification of the short-run structural equations often requires that the residuals are uncorrelated, or at least not significantly correlated since residual covariance matrix plays an important role in the identification of the short-run structure. When the residuals of a short-run structural model are approximately uncorrelated, it might be possible to label them as estimated shocks (Reade, 2006).

Table 3 Short run equilibrium Vector Error Correction Estimate

\begin{tabular}{lccc}
\hline Variables & coefficients & standard error & t-statistics \\
\hline Constant & 0.010545 & 0.01183 & {$[0.89110]$} \\
GDP & $-0.004844^{*}$ & -0.1952 & {$[0.024820]$} \\
Deposit & 0.034763 & -0.03393 & {$[1.02458]$} \\
Investment & 0.121969 & -0.2332 & {$[0.52302]$} \\
Credit & 2.373366 & 0.04625 & {$[51.3183]^{*}$} \\
Foreign currency \&remittance & 0.095943 & -0.56582 & {$[0.16957]$} \\
\hline
\end{tabular}

Source: - own computation result data from NBE, 2016

The coefficient of the lagged error correction measures the speed of adjustment at which GDP would adjust to changes in deposit mobilization, credit, domestic investment, and foreign currency remittance before converging to their equilibrium level. It has the correct sign implying that the series is non-explosive and that long-run equilibrium is attainable. The estimated coefficient (-0.004844) of GDP indicates speed of adjustment to reach the equilibrium following a shock. The negative sign implies the speed of adjustment of disequilibrium in the period of study and hence all the variables are adjusted as shown in the table 4.3. Among independent variables, credit given by private Banks has significant and positive impact on the short run economic growth indicating that given other things constant $23.7 \%$ variation in GDP at short run is from credit provided by private Banks.

\section{Conclusions and Recommendations \\ 4.1 Conclusion}

This study examined the impact of private Banks on Economic growth in Ethiopia by using time series data from 1994/95 to 2015/16. The objective of this study was to show the impact of private commercial Bank on Economic growth in Ethiopia. The study employed VECM to analyze deposit, credit, investment and foreign currency purchase and remittance considered as explanatory variables and economic growth which is measured by GDP was taken as dependent variable. The VECM results revealed deposit mobilization, domestic investment and foreign currency and remittance were positively and significantly influence the economic growth in Ethiopia in long run. On the other hand, among independent variables, credit given by private Banks has significant and positive impact on the short run economic growth. When the deposit mobilization of private Banks increases; it contributes its share significantly to the country's economic growth. Financing the investment sector is one of the primary functions of private Banks that positive impact on the Economic growth in Ethiopia. Therefore, private Banks are playing indispensable role on the Economic growth in Ethiopia by performing their primary functions in the economic activities.

\subsection{Recommendation}

$>$ Private Banks should mobilize deposits from every corner of the country by further increasing their branch network.

\section{References}

Alex E., 2012. The Role of Banks in Capital Formation and Economic Growth: The Case of Nigerian Economy 
Trans disciplinarily Cognition, Vol. 15, 103-11.

Andebet M., 2016. Performance of private commercial Banks in Ethiopia, pre and post NBE bill Periods.

Aurangzeb, 2012. Contributions of Banking Sector in Economic Growth: A Case of Pakistan Economics and Finance Review Vol. 2(6) pp. 45 - 54.

Befikadu A., 2015. The role of private Banks in financing government priority sector projects: The Case of Bank of Abyssinia.

Bezabeh, A., \& Desta, A., 2014. Banking Sector Reform in Ethiopia. International Journal of Business and Commerce, 3 (2225-2436), 25-38.

Gebeyehu A., 2008, "Financial Performance of National Bank of Ethiopia Workers "Savings and Credit Association with special emphasis to adjustments (NBE WSACA)".

Keatinge, T., 2014. The Role of Public and Private Sector Banking in Ethiopia's Future Economic Growth. Retrieved from http://www.globalcenter.org.

Melkamu D., 2015. The Relation between Commercial Bank's Development and Growth in Ethiopia.

Monetary and Banking proclamation No.83/1994 and the Licensing and Supervision of Banking Business No.84/1994. NBE Directive no: MFA/NBEBILLS/001/2011.

Negussie, H., 2012. Determinants of Bank Profitability: An Empirical Study on Ethiopian Private Commercial Banks.

Orji A. (2012), "Bank savings and Bank credits in Nigeria, Determinants and impact on Economic Growth", international Journal of economics and financial Issues vol.2 No.3, 2012, PP 357-372. 